\title{
EVALUATION OF PRODUCTIVE AND PHYSIOLOGICAL PERFORMANCE OF BALADI RED COMPARED TO NEW ZEALAND WHITE RABBITS UNDER THE SAME MANAGERIAL CONDITIONS
}

\author{
H. A. Khalil*, W. H. Kishk, Essa, Omnia M. A. and M. M. Awad \\ Department of Animal Production, Faculty of Agriculture, Suez Canal University, Ismailia, Egypt \\ *Corresponding Email: drhassan_2000@yahoo.com
}

\section{SUMMARY}

This experiment was designed to compare the productive performance, reproductive efficiency, physiological reactions and behavioral traits in males and females of two breeds of rabbits, Baladi Red (BR) and New Zealand White (NZW) rabbit breeds. Fifty two mature males and females rabbits were used in this experiment. Twenty six from each breed were used (6 males and 20 females). At the bigining of the experiment, age of animales averaged 4-5 months and their weight averaged 2.20-2.50 Kg for each breeds.

Results of this study indicated that, there were significant differences between both breeds and sexes on most studied traits. Females had $(P \leq 0.05)$ superior physiological body reactions and lower hematological parameters than those recorded for males, irrespective of breed factor. Howeber, no significant differences were found between breeds on physiological body reactions and hematological parameters, irrespective of sex of breed.

Also, the results showed that, NZW rabbit bucks had significantly $(P \leq 0.05)$ higher libido, whole ejaculate volume, dead spermatozoa, and insignificant higher sperm concentration/ml than those obtained in BR bucks breed. In contrast, BR rabbit bucks had $(P \leq 0.05)$ higher semen $p H$, net ejaculate volume and initial motility, and had insignificant higher sperm concentration/ejaculate than those obtained in NZW bucks breed.

Also, NZW rabbit does had significantly $(P \leq 0.05)$ higher receptivity percent, litter size at weaning, milk yield and walking behavior percent, and had insignificant higher vulva color score, number of parities and litter size at birth than those recorded in BR breed. Contrary, BR rabbit does had $(P \leq 0.05)$ higher, body weight after one year, kindling intervals, average kit weight at weaning, sitting behavior percent, and insignificant higher conception rate than those obtained in NZW rabbit does breed. Moreover, the results showed that, NZW rabbit breed had significantly $(P \leq 0.05)$ lower mortality rate of the youngs than those recorded in BR breed. In relation to adult animals, BR was lower mortality rate than NZW breed. Moreover, the results showed that there was positive correlation between conception rate and most semen characteristics, In contrast there were negative correlations between mortality rate of the young and both female behavioral activities and milk yield.

It is concluded that, libido and semen characteristics in BR bucks seems to be better than those recorded by the WNZ bucks. However, productive and reproductive efficiency in NZW does appears to be higher than those obtained from BR breed, under the same managerial conditions.

\section{Keywords: Rabbits, breed, semen, production, reproduction, physiological reactions, behavior}

\section{INTRODUCTION}

Rabbits have high efficiency in the production of meat compared to other farm animals. For that reason, rabbits can be considered as a source of animal protein and can be subjected to local conditions. Also, rabbit production is correspondence with all levels of production, whether big ones or small ones and therefore, the field investment of rabbit production is available for everyone, especially young people and girls in the countryside. Moreover there are a number of breeds of rabbits which could be more than 40 breed and are bred for different purposes: meat, fur, hair and shows (Stephen et al., 2013).

Egyptian local strains of rabbits could be as follows: Baladi Red, Baladi Black, Mountain rabbits (Gabaly). Baladi Red which was produced at the research stations of the Animal Production Research Institute for more than 50 years and is the result of mixing Baladi rabbit with Felander gray and then selection to the red color was carried out. This strain of rabbits is low in the productive and reproductive performance, and productivity of milk (Khalil, 1999\&2002). Moreover, Khalil (2002) reported that, Baladi red rabbits had higher tolerance to climatic stress and disease resistance compared to the exotic breeds raised in Egypt.

Several studies were carried out to examine productive and reproductive ability of native and exotic breeds under Egyptian conditions; such as, Abd El-Aziz et al. (2002) used Gabali and NZW rabbit breeds and Seleem et al. (2008) used Baladi Black and NZW rabbit breeds. However, there is insufficient information about productive and reproductive performances of Baladi Red compared with NZW breed under the same conditions.

The objective of this study was to assess and evaluate the productive, reproductive, physiological and behavioral traits of a well adapted local breed (Baladi Red, BR) in comparison to a less adapted 
exotic breed (New Zealand White, NZW) under Egyptian environemntal conditionson throughout one year of production.

\section{MATERIALS AND METHODS}

\section{Animals and management}

This experiment was carried out at a rabbitry of the experimental farm belonging to Faculty of Agriculture, Suez Canal University, Ismailia, Egypt. The experiment was done during a complete one year of production from February, (2013) to February, (2014). Rabbits were kept continuously under the same managerial and environmental conditions during the whole experimental period.

Fifty two mature males and females of two different breeds of rabbit 26 (6 males and 20 females) from each breed were used in this study. These breeds were Baladi Red (BR) and New Zealand White (NZW). Animals were healthy and free of any external parasites or skin diseases. At the beginning of the experiment, age of animals averaged 4-5 months and their weight averaged 2.20-2.50 Kg. All rabbits were individually housed in galvanized wired cages, where feed and water were provided ad libitum. Animals were fed on basal pellet ration contained yellow corn, soybean meal, corn gluten, minerals and vitamins premix, bone and molasses. The calculated chemical components of the diet were $17 \%$ crude protein, $2.8 \%$ fat, $10 \%$ crude fiber and $2600 \mathrm{kcal}$ digestible energy/kg diet.
Lighting system was $16 \mathrm{hrs}$ light/ $8 \mathrm{hrs}$ dark in the rabbitry during the experimental period. Does were transferred to the rabbit bucks cages for natural mating process and kept under examination until natural mating was successfully completed.

\section{Experimental design}

Rabbit does were mated according to their body weight $(\mathrm{BW})$. The average $\mathrm{BW}$ at mating ranged between 2.500 to $2.750 \mathrm{~kg}$ for each breed. The mating season started from February until June, $2013\left(1^{\text {st }}\right.$ period) and stopped during July and August (hot season) and restarted again from September to February, 2014 ( $2^{\text {nd }}$ period). Ambient temperature and relative humidity inside rabbitry were recorded daily during the experiment periods by using thermometer and hygrometer. The temperaturehumidity index (THI) was estimated according to thermal comfort level of an animal environment according to Marai et al. (2002) for rabbit is a function of temperature and relative humidity of the enclosure. It was measured according to the following equation: $\quad$ THI $=\mathrm{db}^{\circ} \mathrm{C}-\left[(0.31-0.31 \mathrm{RH})\left(\mathrm{db}^{\circ} \mathrm{C}-\right.\right.$ 14.4)], where $\mathrm{db}{ }^{\circ} \mathrm{C}=$ dry bulb temperature in Celsius and $\mathrm{Rh}=\mathrm{RH} \% / 100$. The estimated values of $\mathrm{THI}$ were classified as follows: less than 22.2=absence of heat stress, 22.2-23.2=moderate heat stress, 23.325.5=severe heat stress and more than 25.5=very severe heat stress (Table 1).

Table 1. Averages of ambient temperature $\left(\mathrm{AT},{ }^{\circ} \mathrm{C}\right)$, relative humidity $(\mathrm{RH}, \%)$ and temperature-humidity index (THI) in the rabbitry during the experimental periods

\begin{tabular}{lccccc}
\hline Periods & \multicolumn{3}{c}{ AT $\left({ }^{\mathbf{0}} \mathbf{C}\right)$} & \multirow{2}{*}{ RT (\%) } & \multirow{2}{*}{ THI } \\
\cline { 2 - 4 } & \multicolumn{1}{c}{ Max } & Min & Mean & & \\
\hline $\mathbf{1}^{\text {st }}$ period (February - June) & $25.8 \pm 0.5$ & $15.0 \pm 0.9$ & $20.4 \pm 0.8$ & $60.7 \pm 7.7$ & 19.9 \\
Rest period ( July-August) & $35.8 \pm 1.5$ & $25.2 \pm 0.8$ & $30.5 \pm 0.7$ & $55.6 \pm 7.7$ & 28.4 \\
$\mathbf{2}^{\text {nd }}$ period (September-February) & $27.5 \pm 3.2$ & $16.8 \pm 2.8$ & $22.2 \pm 2.9$ & $62.3 \pm 5.7$ & 21.0 \\
\hline
\end{tabular}

\section{Experimental studied traits \\ 3.1. Physiological body reactions}

Thermo-cardio-respiratory responses including, rectal temperatures (RT), respiratory rate $(\mathrm{RR})$ and pulse rate $(\mathrm{PR})$ of bucks and does were recorded in the morning between 8:00-10:00 am for each animal. RT was measured in animals by using clinical thermometer which inserting for one minute into the rectum for about $2 \mathrm{~cm}$ from anus oriffice after liniment by pure vaseline. RR was measured by counting the movements of the chest muscles. PR was measured by counting pulses in the femoral artery with a finger for a period of one minute (Kishk et al., 2009).

\subsection{Hematological parameters}

Blood samples were collected from each animal from the ear vein in heparinized tubes during the morning between 8:00-10:00 am. Red blood cells (RBCs) and white blood cells (WBCs) were counted, hemoglobin concentration $(\mathrm{Hb})$ and hematocrit values (Ht) were measured in fresh blood samples using NIHON KOHDEN equipment (automated hematology analyzer).

\subsection{Rabbit semen characteristics}

Semen was collected from the bucks twice/week by using rabbit artificial vagina during November and December, 2013. Reaction time was determined using stopwatch to determine the time that the buck spent to give an ejaculate. Semen characteristics were estimated immediately after collection in each ejaculate such as; semen ejaculates volume, $\mathrm{pH}$ value, initial motility \%, sperm concentration, live and dead sperm percentage. Ejaculate volume was measured to the nearest $0.1 \mathrm{ml}$ using a graduated collection tube. Sperm motility (\%) was estimated microscopically at $400 \mathrm{X}$ by using a drop of diluted semen with a drop of warm $0.9 \%$ saline solution $(\mathrm{NaCl})$ and covered with cover slip on a warm slide. Semen $\mathrm{pH}$ was estimated 
by using $\mathrm{pH}$ indicator papers ranging from 6.0 to 8.0 with 0.2 grades. Sperm concentration per ejaculate was determined using the hemocytometer. The percentage of dead spermatozoa was estimated using eosin-ngrosin stain. Percentage of dead spermatozoa was estimated by counting the number present in 100 sperm in different fields on the slide (Blom, 1983).

\subsection{Productive and reproductive traits of does}

Before mating of each doe, vaginal-vulva status was examined visually and classified into three categories according to the coloration as red pale, rose and dark red (Kishk et al., 2006). Receptivity percent was calculated as a percentage of the number of mated females from all females provided to mating. Conception rate was calculated as a percentage of the number of pregnant females from all mated females. Litter size and weight at birth and weaning were recorded. Kindling intervals, number of parities and mortality rates were recorded during the experimental period. Milk yield for each doe was recorded for one day/week at 8:00 am as the difference in the weight of pups before and after suckling. The pups were separated before suckling for 14 hour at the $1^{\text {st }}, 2^{\text {nd }}, 3^{\text {rd }}, 4^{\text {th }}$ week of lactation period. Reproductive efficiency of does was calculated using the following formula: (number of kits at weaning of breed $\mathrm{A} /$ number of kits at weaning of breed B)*100.

\subsection{Behavioural activities}

Sexual behaviour test of the bucks was recorded during the last month of the experimental period. The aim of this test was to evaluate the sexual behaviour activities of both breeds during 10 minutes. During this test, the female was presented to each male. Semen was collected by artificial vagina. Sexual behavioural traits were estimated according to Anders et al. (1996) such as: number of ejaculations, total semen volume and mounting and ejaculation intervals (min). Also, the behavioral traits of the females were studied after the end of the experimental period using a video camera. All examined females were neither pregnant nor suckling. During this test, each doe transferred into individual cage $(100 \mathrm{~cm} X 50 \mathrm{~cm} X 50 \mathrm{~cm})$. The behavioral traits were recorded for one hour per doe in each breed. From the video tapes, at $5 \mathrm{~min}$ interval (time sampling) the basic activities (percentage of does standing, sitting or walking) were recorded according to Kishk et al. (2008) and Khalil et al. (2009).

\subsection{Statistical analysis}

Data were analyzed using the General Linear Model (GLM) procedure of SAS (SAS Institute Inc., 1998). Differences among means were detected using Duncan's new multiple test (Duncan, 1955). Correlation coefficients among traits were estimated.

The mathematical model used for physiological body reactions and hematological parameters was:

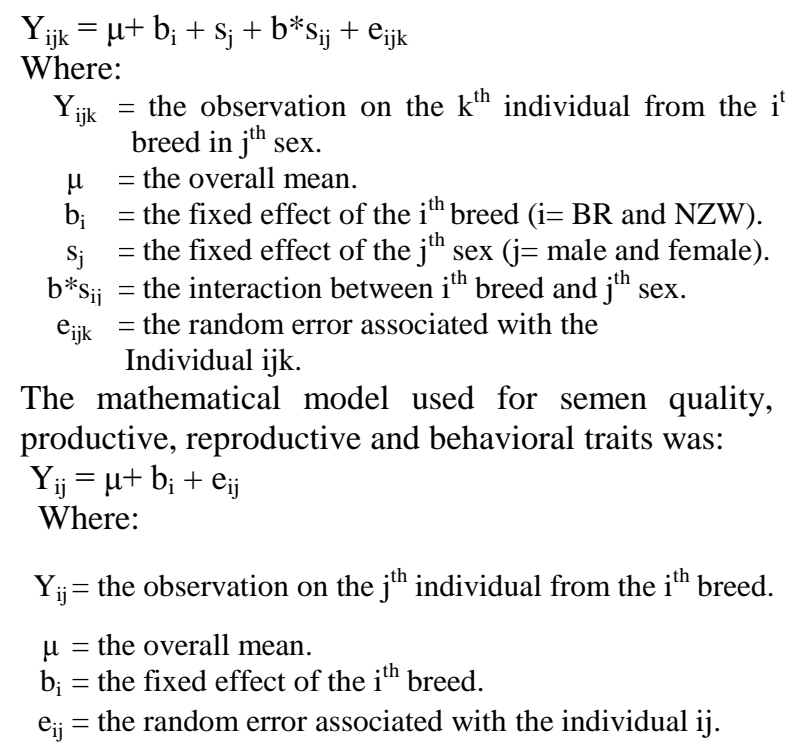

\section{RESULTS AND DISCUSSION}

\section{Physiological body reactions}

Data in Table (2) shows the effect of breed, sex and their interaction on physiological body reactions (RT, RR and PR). Analysis of variance revealed no statistically significant differences due to breed and the interaction between breed and sex in all parameters. On the other hand, there was significant difference $(\mathrm{P} \leq 0.05)$ between the two sexes in all traits. The females had significantly higher RT, RR and PR values than those recorded in the males, irrespective of breed. This result is similar to the results reported by Hebold and Bleuel (1973) who noticed that the female rabbits had higher rectal temperature $\left(39.30^{\circ} \mathrm{C}\right)$ than the males $\left(38.95^{\circ} \mathrm{C}\right)$. Also, Pericin and Grieve (1984) recorded that, the female Chinchilla rabbits showed significantly higher body temperatures than the males. In this respect, Seleem et al. (2008) recorded that, the female rabbits had significantly higher physiological body reactions (RT, RR and PR) than those recorded in males. This difference could be explained in terms of cyclical variation occurring in female animals, which causes increase in metabolic rates and physiological activities of the females (Kihlstrom and Lundberg, 1971). On the other hand, there were no statistically significant differences due to breed and their interactions in all parameters.

\section{Hematological parameters}

Results of hematological parameters including RBCs, WBCs, $\mathrm{Hb}$ and $\mathrm{Ht}$ values of blood samples of bucks and does as affected by breed, sex and their interactions are presented in Table (3). There were no significant differences between breeds and the interaction between sex and breed in all parameters. These results are in agreement with the results obtained by Burnett et al. (2006) who recorded that, breed did not have a significant effect on the hematological parameters in rabbits. Moreover, NZW 
breed had insignificantly lower in all parameters than those recorded in NZW breed. This decline may be due to an increase of reproductive efficiency of NZW breed than BR breed (Table 5). Moreover, significant $(\mathrm{P}<0.05)$ differences were found between the two sexes in all parameters except WBCs. The males had significantly higher $\mathrm{RBCs}, \mathrm{Hb}$ and $\mathrm{Ht}$ and insignificantly higher WBCs values than those recorded in the females, irrespective of breed. These results are in agreement with the results obtained by
Burnett et al. (2006) who recorded that, the male rabbits had significantly higher $\mathrm{RBCs}, \mathrm{Hb}$ and $\mathrm{Ht}$ values than the females. This increment in hematological parameters in the males may be related to sexual hormones. Androgens may increase RBCs production (Kerr, 2002). Also, the reduction in the erythrocyte count and hemoglobin values in the female animals, may be related to the physiological anaemia occurring due to hemodilution (Ozegbe, 2001).

Table 2. Physiological body reaction of BR and NZW rabbits (Means \pm SE)

\begin{tabular}{lcccc}
\hline Parameters & \multirow{2}{*}{ Sex } & \multicolumn{2}{c}{ Breed } & \multirow{2}{*}{ Overall } \\
\cline { 3 - 4 } & & BR & NZW & $38.27 \pm 0.07^{\mathrm{B}}$ \\
Rectal temperature $\left({ }^{\mathbf{0}} \mathbf{C}\right)$ & Male & $38.30 \pm 0.11$ & $38.24 \pm 0.08$ & $38.86 \pm 0.05^{\mathrm{A}}$ \\
& Female & $38.78 \pm 0.07$ & $38.95 \pm 0.06$ & 38.86 .05 \\
Respiration rate $(\mathbf{R} / \mathbf{m})$ & Overall & $38.56 \pm 0.05$ & $38.58 \pm 0.05$ & \\
& Male & $125.91 \pm 3.22$ & $119.63 \pm 1.26$ & $123.75 \pm 2.36^{\mathrm{B}}$ \\
& Female & $150.24 \pm 3.71$ & $151.73 \pm 4.72$ & $151.03 \pm 3.45^{\mathrm{A}}$ \\
& Overall & $138.58 \pm 3.45$ & $135.68 \pm 3.98$ & \\
Pulse rate $(\mathbf{P} / \mathbf{m})$ & Male & $133.45 \pm 1.85$ & $129.70 \pm 1.56$ & $131.61 \pm 1.25^{\mathrm{B}}$ \\
& Female & $149.79 \pm 3.64$ & $154.36 \pm 5.25$ & $152.35 \pm 3.28^{\mathrm{A}}$ \\
\hline
\end{tabular}

${ }^{\mathrm{A}, \mathrm{B}}$ Means within column not sharing a common superscript differed significantly $(P \leq 0.05)$.

Table 3. Hematological parameters of BR and NZW rabbits (Means \pm SE)

\begin{tabular}{lcccc}
\hline Parameters & \multirow{2}{*}{ Sex } & \multicolumn{2}{c}{ Breed } & \multirow{2}{*}{ Overall } \\
\cline { 3 - 4 } RBCs $(\mathbf{x 1 0} / \mathbf{m l})$ & Male & $5.80 \pm 0.12$ & $5.66 \pm 0.52$ & $5.73 \pm 0.15^{\mathrm{A}}$ \\
& Female & $5.47 \pm 0.25$ & $5.25 \pm 0.21$ & $5.35 \pm 0.18^{\mathrm{B}}$ \\
& Overall & $5.56 \pm 0.21$ & $5.42 \pm 0.20$ & \\
WBCs $(\mathbf{x 1 0} / \mathbf{m l})$ & Male & $9.12 \pm 1.25$ & $7.33 \pm 1.53$ & $8.23 \pm 1.08$ \\
& Female & $8.30 \pm 0.91$ & $7.40 \pm 1.21$ & $7.81 \pm 0.95$ \\
Hemoglobin $(\mathbf{g} / \mathbf{1 0 0 m l})$ & Overall & $8.61 \pm 0.88$ & $7.35 \pm 1.52$ & \\
& Male & $13.27 \pm 0.23$ & $13.01 \pm 0.22$ & $13.14 \pm 0.20^{\mathrm{A}}$ \\
& Female & $12.30 \pm 0.25$ & $11.77 \pm 0.31$ & $12.05 \pm 0.19^{\mathrm{B}}$ \\
Hematocrit $(\%)$ & Overall & $12.80 \pm 0.26$ & $12.35 \pm 0.31$ & \\
& Male & $39.16 \pm 0.44$ & $38.03 \pm 0.52$ & $38.59 \pm 0.32^{\mathrm{A}}$ \\
& Female & $36.87 \pm 0.61$ & $35.80 \pm 0.65$ & $36.15 \pm 0.42^{\mathrm{B}}$ \\
\hline
\end{tabular}

A,B Means within column not sharing a common superscript differed significantly $(P \leq 0.05)$.

Table 4. Libido and semen characteristics evaluation of BR and NZW rabbit bucks (Means \pm SE)

\begin{tabular}{|c|c|c|}
\hline \multirow{2}{*}{ Parameters } & \multicolumn{2}{|c|}{ Breed } \\
\hline & BR & NZW \\
\hline Libido (sc) & $22.47 \pm 0.61^{\mathrm{b}}$ & $28.33 \pm 0.91^{\mathrm{a}}$ \\
\hline Whole ejaculate volume (ml) & $0.91 \pm 0.62^{b}$ & $1.29 \pm 0.05^{\mathrm{a}}$ \\
\hline Net ejaculate volume $(\mathrm{ml})$ & $0.52 \pm 0.02^{\mathrm{a}}$ & $0.38 \pm 0.02^{b}$ \\
\hline Semen $p H$ value & $7.77 \pm 0.01^{\mathrm{a}}$ & $7.16 \pm 0.28^{b}$ \\
\hline Initial motility $(\%)$ & $74.05 \pm 1.42^{\mathrm{a}}$ & $66.18 \pm 1.61^{\mathrm{b}}$ \\
\hline Dead spermatozoa $(\%)$ & $11.81 \pm 0.43^{b}$ & $18.60 \pm 0.52^{\mathrm{a}}$ \\
\hline Sperm concentration $(\mathbf{x 1 0} / \mathrm{ml})$ & $411.27 \pm 13.71$ & $443.13 \pm 12.91$ \\
\hline Sperm concentration ( $\times 10^{6} /$ jaculate $)$ & $206.73 \pm 13.83$ & $172.86 \pm 11.63$ \\
\hline
\end{tabular}

${ }^{\mathrm{a}, \mathrm{b}}$ Means within row not sharing a common superscript differed significantly $(P \leq 0.05)$.

\section{Libido and semen characteristics}

The effect of breed on libido and semen characteristics of rabbit bucks are presented in Table (4). BR breed had significantly higher $(\mathrm{P} \leq 0.001)$ net ejaculate volume (without gel portion), semen $\mathrm{pH}$ and sperm initial motility and lower $(\mathrm{P} \leq 0.001)$ reaction time, whole ejaculate volume (with gel portion) and dead spermatozoa $(\%)$ and insignificantly lower sperm concentration ( $\times 10^{6} / \mathrm{ml} \& \times 10^{6} /$ jaculate $)$ than those recorded in NZW bucks breed. 
These results are comparable with those obtained by Meshreky et al. (2005) who compared Baladi Red breed with V-line rabbit bucks. Also, Safaa et al. (2008) and Seleem et al. (2008) recorded that BB rabbit bucks performed significantly better than NZw bucks in terms of libido and semen characteristics or sperm production under the environmental conditions in Egypt. The differences among breed groups in libido and semen quality may be due to the variations in pituitary gland activity that can affect the secretion of luteinizing hormone which affects the secretion of testosterone from the interstitial tissues of the testes (Seleem, 2003).

\section{Productive and reproductive traits}

Results in Table (5) show the effect of breed on productive and reproductive traits. BR breed recorded significantly superior kindling interval (days), mortality rate of young (\%) and body weight of does after one year $(\mathrm{g})$, than these recorded in NZW breed. In contrast, NZW breed recorded significantly higher receptivity (\%), average total litter size (no/doe) at weaning and average litter size (no/parity) than those recorded in BR breed.

On the other hand, BR had insignificantly higher conception rate (\%) and average kit weight at weaning ( $g$ ) than those obtained in NZW breed. In this respect, NZW breed had insignificantly higher vulva color, average total litter size at birth (no/doe), average total litter weight at weaning/doe/parity and number of parities than those recorded in BR breed. However, mortality rate of the adult animals was higher in NZW breed compared to BR breed.

These results are partially in agreement with those obtained by Seleem et al. (2008) using Baladi Black and NZW rabbits. They found that, Baladi Black had significantly higher conception rate, kindling rate and kits weight at weaning than those recorded in NZW breed. The difference in reproductive traits among the breeds may be due to the changes in the physiological efficiency of rabbit does (El-Maghawry et al., 1999).

Also, several investigations reported that, kindling intervals are longer in BR does than in NZW breed. Youssef (1992) and Khalil (2002) Abd El-Halim (2003) and Gharib (2008) recorded that kindling interval (days) of BR breed ranged between 49 to 78 day. On the other hand, El-Gaafary et al. (1992), Abd El-Raouf (1993) and Marai et al. (2006) reported that kindling interval of NZW breed ranged between 41.3 to 43.6 days. This may be due to a high number of Kindling intervals of BR breed which is having poor receptivity since their first mating after kindling (Khalil, 2002).

On the other hand, many workers did not find significant differences between two breeds in average litter size at birth. Khalil (2002), Mabrouk et al. (2008) and Gharib (2008) reported that average litter size at birth of BR ranged between 6.2 to 6.6/doe. Marai et al. (2006) and Abdel-Monem (2009) reported that the average litter size at birth of NZW rabbit ranged between 6.5 to 6.9/doe. Moreover, other researchers recorded significant differences between breeds in average litter size at weaning, NZW breed had increased number than BR breed. Moreover, Khalil et al. (1995) reported that, the average litter size at weaning of BR ranged between 3.4 to 3.7/doe. Abdel-Samee et al. (1994) and Hassanien and Baiomy (2011) reported that the average litter size at weaning of NZW rabbit ranged between 4.1 to 4.5/doe.

The reason for few numbers of kits at weaning in BR compared with NZW breed is due to increased mortality rate of kits. Some researchers recorded this point. Galal and Khalil (1994) reported that the average pr-weaning mortality rate of BR ranged between 35 to $60.2 \%$, but it ranged between 23.18 to $48.7 \%$ in NZW breed (Tawfeek and Hindawy, 1991, El-Bogdady et al., 1992 and Galal and Khalil, 1994). Increasing pre-weaning mortality rate of BR may be related to decrease fairly the maternal ability of doe to suckle its kids (El-Maghawry et al., 1999).

\section{Milk yield}

The effects of breed on the average weekly milk yield (MY) during the four weeks from birth to weaning are presented in (Table 6). Analysis of variance revealed that, there were highly significant differences $(\mathrm{P}<0.01)$ between breeds in the average weekly MY. NZW breed recorded significantly higher average weekly MY than those recorded in BR breed.

These results agree with those reported by ElMaghawry (1993), Bassuny (1999), Khalil (2002) and Gad Alla et al. (2005) who recorded that, the average range of total milk yield in NZW breed was higher than that recorded in BR throughout the four weeks. The higher MY of NZW rabbit does reflect a good maternal genetic characterises in milk production. This trait may be important factor to reducing the mortality rate of kits from birth to weaning in NZW breed compared to BR breed.

\section{Behavioral activities traits a- Sexual activities of bucks}

The effect of breed on some sexual behavioral activities of rabbit bucks including mounting and ejaculation intervals (min), number of ejaculations and total semen volume (ml) (across 10 minutes) are presented in Table (7). NZW bucks breed had significantly $(\mathrm{P} \leq 0.05)$ higher number of ejaculations and total semen volume and lower $(\mathrm{P} \leq 0.05)$ ejaculation intervals and insignificant lower mounting intervals than those recorded in BR bucks breed. This test showed that, NZW bucks breed had better sexual behavior activities than BR bucks breed under the same conditions.

\section{b- Basic activities of does}

Effects of breed on behavioral activities traits of rabbit does are presented in Table (7). BR does breed had significantly $(\mathrm{P} \leq 0.05)$ higher percentage of walking and lower percentage of sitting than those 
recorded in NZW breed. On the other hand, there were no significant differences between breeds on walking percent.

Our results showed that does of NZW breed had more activity than BR breed. The higher behavioral activity of NZW rabbit does reflect a good maternal behavior towards their kits. These results may explain the decline in the mortality rate of kits from birth to weaning stage for NZW breed compared to that in BR breed. Also, these results indicate that there is a poor maternal behavior of BR breed towards their kits which caused increased mortality rates during the same period.

\section{Correlation coefficients between some productive and reproductive traits}

The correlation coefficients between some productive and reproductive traits are presented in Table 8 . The results showed that there were varied relationships between studied traits, but we focused only on the most important relationships.

Significant $(\mathrm{P} \leq 0.05)$ positive correlations were found between net semen ejaculate and initial motility percent, sperm concentration/ejaculate, and conception rate. Also, between initial motility percent and conception rate. As well, between receptivity and vulva color, milk yield, and female activity. Also, between kindling intervals and mortality rate of the young. In contrast, significant $(\mathrm{P} \leq 0.05)$ negative correlation were found between reaction time and net semen ejaculate, dead spermatozoa percent, and sperm concentration/ ejaculate. Also, between conception rate and receptivity percent, milk yield and female activity. As well, between receptivity and kindling intervals. Also, between mortality rate of the young and receptivity, vulva color, milk yield, and female activity.

Table 5. Productive and reproductive traits of BR and NZW rabbit does (Means \pm SE)

\begin{tabular}{|c|c|c|c|}
\hline \multirow{2}{*}{ Parameters } & \multicolumn{2}{|c|}{ Breed } & \multirow{2}{*}{ P value } \\
\hline & $\mathbf{B R}$ & NZW & \\
\hline Doe weight at mating & $2642.50 \pm 38$ & $2648.75 \pm 28.4$ & 0.897 \\
\hline Doe weight after one year & $3497.50 \pm 10.71^{\mathrm{a}}$ & $3100 \pm 9.53^{b}$ & 0.015 \\
\hline Kindling interval (days) & $62.17 \pm 5.34^{\mathrm{a}}$ & $42.84 \pm 4.23^{b}$ & 0.008 \\
\hline Receptivity (\%) & $32.45 \pm 6.34^{b}$ & $61.61 \pm 7.23^{\mathrm{a}}$ & 0.003 \\
\hline Conception rate $(\%)$ & $93.10 \pm 4.81$ & $87.88 \pm 5.35$ & 0.496 \\
\hline Vulva color (score) & $2.38 \pm 0.14$ & $2.42 \pm 0.12$ & 0.724 \\
\hline \multicolumn{4}{|l|}{ Average litter size (no/parity) } \\
\hline at birth (no) & $6.60 \pm 0.41$ & $6.98 \pm 0.32$ & 0.861 \\
\hline at weaning (no) & $3.34 \pm 0.38^{\mathrm{b}}$ & $4.48 \pm 0.31^{\mathrm{a}}$ & 0.023 \\
\hline \multicolumn{4}{|c|}{ Average total litter weight/doe/parity } \\
\hline at birth $(\mathrm{g})$ & $440.15 \pm 30.88$ & $439.97 \pm 17.05$ & 0.996 \\
\hline at weaning (g) & $1288.35 \pm 102.21$ & $1440.47 \pm 80.08$ & 0.101 \\
\hline \multicolumn{4}{|l|}{ Average Kit weight } \\
\hline at birth $(\mathrm{g})$ & $65.28 \pm 0.93$ & $67.28 \pm 1.48$ & 0.275 \\
\hline at weaning (g) & $333.31 \pm 4.88$ & $314.03 \pm 9.61$ & 0.109 \\
\hline No of parities & $3.25 \pm 0.52$ & $3.88 \pm 0.51$ & 0.378 \\
\hline \multicolumn{4}{|l|}{ Average total litter size (no/doe) } \\
\hline at birth (no) & $22.48 \pm 3.01$ & $25.51 \pm 2.97$ & 0.491 \\
\hline at weaning (no) & $10.85 \pm 1.35^{b}$ & $17.38 \pm 2.66^{\mathrm{a}}$ & 0.034 \\
\hline Mortality rate of young's (\%) & $50.15 \pm 4.78^{\mathrm{a}}$ & $31.62 \pm 4.56^{\mathrm{b}}$ & 0.001 \\
\hline Mortality rate of does (\%) & 5.00 & 15.00 & \\
\hline Reproductive efficiency (\%) & 62.42 & 160.18 & \\
\hline
\end{tabular}

${ }^{\mathrm{a}, \mathrm{b}}$ Means within row not sharing a common superscript differed significantly $(P \leq 0.05)$.

Table 6. Average weekly milk yield of BR and NZW rabbit does (gm/day/doe, Means \pm SE)

\begin{tabular}{lcc}
\hline \multirow{2}{*}{ Week } & \multicolumn{2}{c}{ Breed } \\
\cline { 2 - 3 } & $\mathbf{B R}$ & $\mathbf{N Z W}$ \\
\hline $\mathbf{1}$ & $101.73 \pm 0.33^{\mathrm{b}}$ & $108.75 \pm 0.40^{\mathrm{a}}$ \\
$\mathbf{2}$ & $113.38 \pm 0.62^{\mathrm{b}}$ & $152.50 \pm 1.32^{\mathrm{a}}$ \\
$\mathbf{3}$ & $135.25 \pm 0.61^{\mathrm{b}}$ & $165.46 \pm 0.72^{\mathrm{a}}$ \\
$\mathbf{4}$ & $73.13 \pm 1.04^{\mathrm{b}}$ & $96.50 \pm 0.61^{\mathrm{a}}$ \\
Overall & $105.87 \pm 0.33^{\mathrm{b}}$ & $130.81 \pm 0.21^{\mathrm{a}}$ \\
\hline
\end{tabular}

\footnotetext{
${ }^{\mathrm{a}, \mathrm{b}}$ Means within row not sharing a common superscript differed significantly $(P \leq 0.05)$.
} 
Table 7. Sexual behavior traits of bucks and basic behavior traits of does (Means \pm SE)

\begin{tabular}{lccc}
\hline \multirow{2}{*}{ Behavioral Traits } & \multicolumn{2}{c}{ Breed } & \multirow{2}{*}{ P value } \\
\cline { 2 - 3 } a- Sexual traits of bucks & BR & NZW & 0.048 \\
Mounting interval (min) & $3.88 \pm 0.14^{\mathrm{a}}$ & $2.25 \pm 0.42^{\mathrm{b}}$ & 0.871 \\
Ejaculation interval (min) & $4.72 \pm 0.79$ & $4.45 \pm 1.41$ & 0.043 \\
$\quad$ Number of ejaculations & $2.33 \pm 0.15^{\mathrm{b}}$ & $2.70 \pm 0.18^{\mathrm{a}}$ & 0.000 \\
Total semen volume (m) & $1.55 \pm 0.15^{\mathrm{b}}$ & $2.63 \pm 0.12^{\mathrm{a}}$ & \\
& & & 0.949 \\
b- Basic behavior traits of does & $39.48 \pm 3.92$ & $39.92 \pm 6.74$ & 0.050 \\
Standing (\%) & $19.13 \pm 4.36^{\mathrm{b}}$ & $37.21 \pm 8.15^{\mathrm{a}}$ & 0.049 \\
Walking (\%) & $41.39 \pm 7.25^{\mathrm{a}}$ & $22.75 \pm 5.76^{\mathrm{b}}$ & \\
Sitting (\%) & & & \\
\hline
\end{tabular}

${ }^{\mathrm{a}, \mathrm{b}}$ Means within row not sharing a common superscript differed significantly $(P \leq 0.05)$.

Table 8: Correlation coefficients between some productive and reproductive traits

\begin{tabular}{|c|c|c|c|c|c|c|c|c|c|c|c|c|c|c|}
\hline & NE & IM & DS & SCE & CR & Rec & $\mathrm{VC}$ & KI & $\mathbf{N P}$ & KNB & KNW & MY & FAct & MRY \\
\hline RT & $-.431 *$ & -.251 & $-.547 * *$ & $-.437 * *$ & -.333 & & & & & & & & & \\
\hline NE & 1.00 & $.460^{*}$ & $-.361 *$ & $.861 * *$ & $.453^{*}$ & & & & & & & & & \\
\hline IM & & 1.00 & $-.529 * *$ & .217 & $.486^{* * *}$ & & & & & & & & & \\
\hline DS & & & 1.00 & -.117 & $-.748^{* *}$ & & & & & & & & & \\
\hline SCE & & & & 1.00 & -.236 & & & & & & & & & \\
\hline CR & & & & & 1.00 & $-.503 *$ & -.258 & .312 & .092 & .182 & -.219 & $-.532 *$ & $-.520 *$ & .495 \\
\hline Rec & & & & & & 1.00 & $.552 *$ & -.607 & .083 & -.002 & .305 & $.723 * *$ & $.762 * *$ & $-.744 * *$ \\
\hline $\mathrm{VC}$ & & & & & & & 1.00 & -.507 & $.563^{*}$ & $.576^{*}$ & $.627 * *$ & $.679 * *$ & $.653^{* *}$ & $-.701 * *$ \\
\hline KI & & & & & & & & 1.00 & .064 & .063 & -.100 & $-.659^{* *}$ & $-.699^{* *}$ & $.716^{* *}$ \\
\hline NP & & & & & & & & & 1.00 & $.901 * *$ & $.666^{* * *}$ & .254 & .155 & -.287 \\
\hline KNB & & & & & & & & & & 1.00 & $.795^{* * *}$ & .176 & .032 & -.115 \\
\hline KNW & & & & & & & & & & & 1.00 & .429 & .231 & -.219 \\
\hline MY & & & & & & & & & & & & 1.00 & $.950 * *$ & $-.907^{* *}$ \\
\hline FAct & & & & & & & & & & & & & 1.00 & $-.964 * *$ \\
\hline MRY & & & & & & & & & & & & & & 1.00 \\
\hline
\end{tabular}

$\mathrm{RT}=$ Reaction time, NE= Net ejaculate, IM= Initial motility, DS= Dead spermatozoa, $\mathrm{SCE}=$ Sperm concentration/ejaculate, $\mathrm{CR}=$ conception rate, $\mathrm{Rec}=$ Receptivity, $\mathrm{VC}=\mathrm{Vulva}$ color, $\mathrm{KI}=$ Kindling Intervals, $\mathrm{NP}=$ Number of parities, $\mathrm{KNB}=\mathrm{kits}$ number at birth, KNW= kits number at weaning, MY= Milk yield, FAct= Female Activity, YMR=Mortality rate of young, $*=(\mathrm{P} \leq 0.05), * *=(\mathrm{P} \leq 0.01)$.

Our results indicated that semen characteristics of BR rabbit bucks were better than those recorded in NZW rabbit bucks. This fact was reflected in conception rate in BR does breed when compared with NZW does breed, where positive correlation was found between conception rate and most semen characteristics (Table 8). However, some productive and reproductive performance parameters of NZW were little higher than those obtained from BR breed. This result may be due to the suggested points:1) higher receptivity percent, 2) lower kindling intervals, 3) lower mortality rates of the young in NZW rabbits. Moreover, positive correlations were found between kits number at weaning and receptivity percent, number of parities and milk yield, and negative correlation with mortality rate of the young and kindling intervals in NZW rabbits (Table 8).

Moreover, lower mortality rates of the young in NZW breed compared to BR breed may be due to: 1) higher milk yield, 2) increase female behavioral activities (maternal behavior) of NZW does breed compared with BR does breed. In this respect, the results revealed that there were significant $(\mathrm{P} \leq 0.01)$ negative correlations between mortality rates of the young and both female behavioral activities and milk yield in BR rabbits (Table 8).

In conclusion, sexual libido and semen characteristic in BR bucks were better than those recorded by the WNZ bucks. However, productive and reproductive efficiency in NZW does appear to be higher than those obtained from BR breed under the same managerial conditions.

\section{ACKNOWLEDGMENTS}

The authors would like to thank Department of Animal Production, Faculty of Agriculture, University of Suez Canal for his efforts during this study.

\section{REFERENCES}

Abd El-Aziz, M.M., E.A. Afifi, Bedier, Nayera Z., A.A. Azamel and M.H. Khalil, 2002. Genetic evaluation of milk production and 
litter weight traits in Gabali, New-Zealand White rabbits and their crosses in a newly reclaimed area of Egypt. $3^{\text {rd }}$ Conference on Rabbit Production in Hot Climates, 8-11 October, Hurghada, Egypt, 103-116.

Abd El-Halim, H.A., 2003. Comparative studies on the performance of some genotypes of rabbits. M.Sc. Thesis, Faculty of Agriculture, Cairo University, Egypt.

Abdel-Monem, U.M., 2009. Effect of remating interval and mating type on some productive and reproductive performance traits of New Zealand White doe rabbits under summer Egyptian conditions. World Rabbit Science, 1: 23-36.

Abd El-Raouf, H.M., 1993. Genetic studies for some economic traits in rabbits. M.Sc. Thesis, Faculty of Agriculture, Moshtohor, Zagazig University, Banha Branch, Egypt.

Abdel-Samee, A.M., K.M. El-Gendy and H. Ibrahim, 1994. Rabbit growth and reproductive performance as influenced by feeding desert forage (Acacia saligna and Atriplex nummlaria) at North Sinai. Egyptian Journal of Rabbit Science, 1: 25-36.

Anders, A., G.P. Raul, J.R. Ignaci and L.C. Jose, 1996. Dopamine and sexual behavior in the male rabbit. Pharmacology Biochemistry and Behavior, 2: 289-295.

Bassuny, S.M., 1999. Performance of doe rabbits and their weanling as affected by heat stress and their alleviation by nutritional means under Egyptian conditions. Egyptian Journal of Rabbit Science, 1: 73-89.

Blom, E., 1983. Pathological condition in the genital organs in the semen as grounds for rejection of breeding bulls for import or export to or from Denmark. Nordisk Veterinaermedicin, 35:105-130.

Burnett, N., K. Mathura, K.S. Metivier, R.B. Holder, G. Brown and M. Campbell, 2006. An investigation into haematological and serum chemistry parameters of rabbits in Trinidad. World Rabbit Science, 14: 175 - 187

Duncan, D.B., 1955. Multiple range and multiple Ftest. Biometrics, 11:1- 42.

El-Bogdady, A.H., A.K.I. Abd El-Moty, A.A. Abd El-Hakeem and H. Hassanein, 1992. Effect of lighting system and breed on productive and reproductive performance of females rabbits. Egyptian Journal of Rabbit Science, 1: 23-36.

El-Gaafary, M.N., A.A. Rashwan, D.M.A. ElKerdawy and K.A. Yamani, 1992. Effects of feeding pelleted diet supplemented with probiotic (Lacto-Sacc) on digestibility, growth performance, blood constituents, semen characteristics and reproductive traits of rabbits. Egyptian Journal of Rabbit Science, 2: 95-105.

El-Maghawry, A.M., Ahmed, Soad S., K.A. Yamani and H. Radwan, 1999. Some reproductive and productive traits of New-Zealand White, Rex rabbits and their crosses. Egyptian Journal of Rabbit Science, 2: 159-177.

El-Maghawry, A.M., 1993. Post-weaning daily gain and mortality rate in New Zealand White and Californian rabbits as affected by some genetic and environmental factors, under Egyptian conditions. Egyptian Journal of Rabbit Science, 1: 91-102.

Gad Alla, S.A.Z., M.A. Abo Marda and Mahgoub, Samia M., 2005. Reproductive performance, litter traits and milk production of Baladi Red, V-Line rabbit breeds and their crosses under Egyptian Environmental conditions. Egyptian Journal of Rabbit Science, 15: 4561.

Galal, E.S.E. and M.H. Khalil, 1994. Development of rabbit industry in Egypt. $1^{\text {st }}$ International Coference of Rabbit Production in Hot Climate, Cairo, Egypt, 43-55.

Gharib, M.G., 2008. A study of some productive and reproductive traits and growth rates in Baladi Red and Bauscat rabbits and their crosses. M.Sc. Thesis, Faculty of Agriculture, Al-Azhar University, Nasr-City, Cairo, Egypt.

Hassanien, H.H.A. and A.A. Baiomy, 2011. Effect of breed and parity on growth performance, litter size, litter weight, conception rate and semen characteristics of medium size rabbits in hot climates. Egyptian Poultry Science, 31: 97-110.

Hebold, G. and H. Bleuel, 1973. Standartwerte im vollblut und serum beim Kaninchen. Arzneimittel Forschung, 23: 1079-1081.

Kerr, M., 2002. Veterinary Laboratory Medicine: Clinical Biochemistry and Haematology, $2^{\text {nd }}$ Ed. Oxford: Blackwell Publications

Khalil, H.A., W.H. Kishk and M.A. Yaseen, 2009. Some physiological, behavioral, reproductive and productive traits of White New Zealand rabbit doe as affected by vulva color. The $2^{\text {nd }}$ Egyptian Conference of Rabbit Science. Cairo University, Cairo, Egypt, 106-119.

Khalil, M.H., 1999. Rabbit genetic resources of Egypt. Animal Genetic Resources Information, No. 26.

Khalil, M.H., 2002. Rabbit genetic resources in Mediterranean countries. Options Méditerranéennes, serie B, No. 38, 39-50.

Khalil, M.H., E.A. Afifi, Y.M.K. Youssef and A.F. Khadr, 1995. Heterosis, maternal and direct genetic effects for litter performance and reproductive intervals in rabbits crosses. World Rabbit Science, 3: 99-105.

Kihlstrom, J.E. and C. Lundberg, 1971. Cyclic variation of body temperature in female rabbits before and after ovariectomy. Acta Physiologica Scandinavica, 82: 272-276.

Kishk, W.H., H.A. Khalil, A.M. Hassanein and M.A. Ayoub, 2006. Physiological, reproductive 
and productive traits of New Zealand White rabbits doe as affected by natural mating time. Egyptian Journal of Rabbit Science, 2: 223-232.

Kishk, W.H., H.A. Khalil and A.M. Hanafy, 2008. Effects of GnRH injection on some reproductive, physiological and behavioural traits in White New Zealand Rabbit does. Egyptian Society for Animal Reproduction and Fertility. In Proc. $20^{\text {th }}$ Annual Congress. Al-Fayoum, Egypt, 175182.

Kishk, W.H., Tharwat, Rabaa A., H.A. Khalil and M.A. Ayoub, 2009. Seasonal effects on White New Zwaland and Californian rabbit bucks semen characteristics, hematological parameters and body reaction performance in Egypt. $5^{\text {th }}$ International Poultry Conference, Taba, Egypt, 1582-1590.

Mabrouk, M.M., M.A. Abul-Hussan, G.E.Y. Attalah, A. Farid and M.G. Gharib, 2008. Evaluation of crossbreeding effects for some litter traits in crossing of Californian with Egyptian Baladi Red rabbits. Egyptian Journal of Rabbit Science, 2: 153-144.

Marai, I.F.M., A.A.M. Habeed and A.E. Gad, 2002. Rabbits productive, reproductive and physiological performance traits as affected by heat stress: a review. Livestock Production Science, 78: 71-90.

Marai, I.F.M., A.A. Askar and L.B. Bahgat, 2006. Tolerance of New Zealand White and Californian doe rabbits at first parity to the subtropical environment of Egypt. Livestock Production Science, 104:165-170.

Meshreky, S.Z., S.A. Gad Alla and M.M. Arafa, 2005. Growth performance, carcass traits, physiological response and economical efficiency of Baladi Red, V-Line rabbits and their cross under Egyptian environmental conditions. In Proc: The $4^{\text {th }}$ International Conference on Rabbit
Production in Hot Climate, Sharm ElSheikh, Egypt, 197-210.

Ozegbe, P.C., 2001. Influence of pregnancy on some erythrocyte biochemical profiles in the rabbits. African Journal of Biomedical Research, 4: 35- 137.

Pericin, C. and A.P. Grieve, 1984. Seasonal variation of temperatures in rabbits. Laboratory Animals, 18: 230-236.

Safaa, H.M., M.E. Emarah and N.F.A. Saleh, 2008. Seasonal effects on semen quality in Black Baladi and White New Zealand rabbits bucks. World Rabbits Science, 16: 13-20.

SAS, 1998. Statistical Analysis System. Users Guide: Statistics. SAS Ins., Cary, NC. USA.

Seleem, T.S.T., 2003. Studies on productive and physiological characteristics of rabbits under different managerial conditions. Ph.D. Thesis, Faculty of Agriculture, Zagazig University, Zagazig, Egypt.

Seleem, T.S.T., M.F.S. Hanna, M.A. Elsawy and A.A. Azoz, 2008. Performance and physiological capabilities of New Zealand White and Baladi Black Rabbits and their crosses under Egyptian environmental conditions. The $1^{\text {st }}$ Egyptian Conference on Rabbit Sciences, Animal Production Department, Faculty of Agriculture, Cairo University, Cairo, Egypt, 61-70

Stephen, M., M. Wanyoike and J. Serem, 2013. Rabbit breed characteristics, farmer objectives and preferences in Kenya: A correspondence analysis. Munich Personal RePEc Archive, Paper No. 48476.

Tawfeek, M.I. and M.M. El-Hindawy, 1991. Reproduction and growth performance of NWZ and Cal rabbits as affected by supplementation with lacto-sacc during summer. Egyptian Journal of Rabbit Science, 2: 124-135.

Youssef, M.K., 1992. The Productive performance of purbreed and crossbreed rabbits. M.Sc. Thesis, Faculty of Agriculture, Moshtohor, Zagazig University, Banha Branch, Egypt. 


\section{تقييم الأداء الإنتاجي و الفسيولوجي للأرانب البلدي الأحمر مقارنة بالأرانب النيوزيلاندى الأبيض تحت نفس ظروف الرعاية}

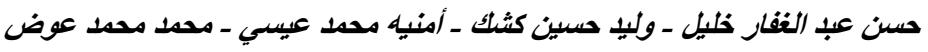 \\ قسم الإنتاج الحيوانس، كلية الزراعة، جامعة قناة السويس، الإسعاعيلية، مصر.}

أجريث هذه التجربة بهدف مقارنة الآداء الإنتاجى، الكفاءه التناسلية، الحالة الفسيولجية، الصفات السلوكية لذكور و إناث سلالتي البلاى الألى الحمر

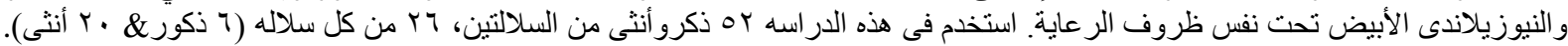

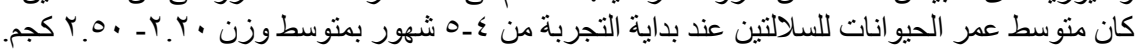
أوضحت النتائج مايلى:

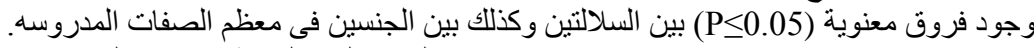

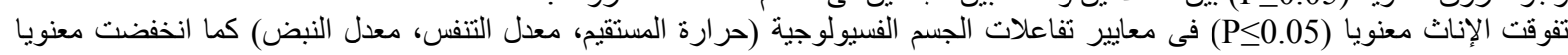

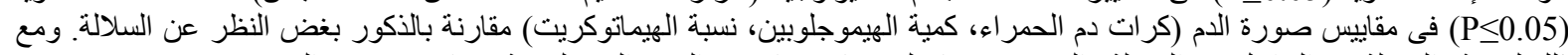

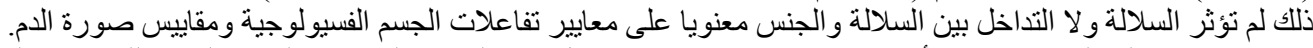

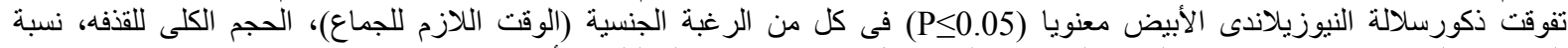

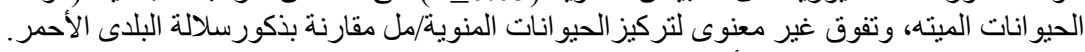

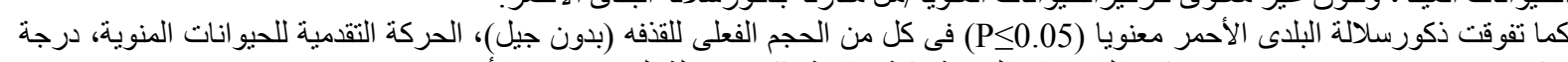

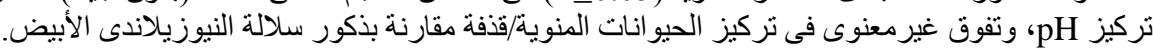

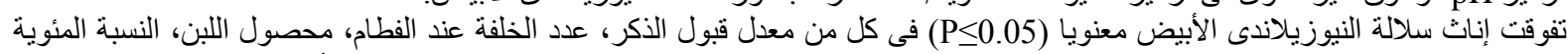

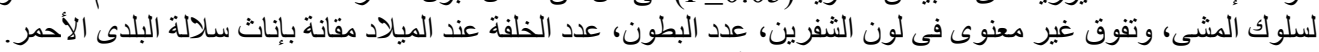

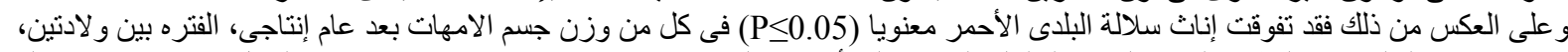

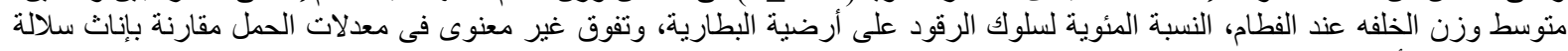

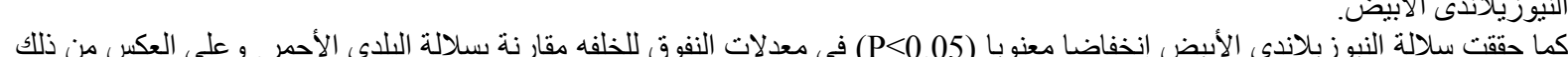

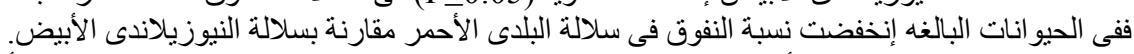

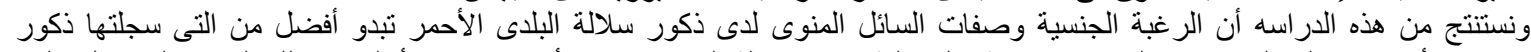

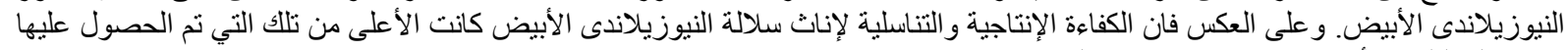

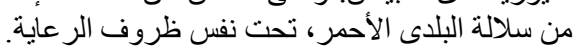

